\title{
Community Resilience: A Case Study of a Community of Fortaleza, CE
}

\author{
Ana Tercila Campos Oliveira*,1 \\ Orcid.org/0000-0001-7254-3969 \\ Normanda Araujo de Morais ${ }^{1}$ \\ Orcid.org/0000-0003-3156-4688
}

${ }^{1}$ Universidade de Fortaleza, Fortaleza, CE, Brasil

\begin{abstract}
The study aims to understand community resilience processes (CR) and their related factors, through a case study of a community in Fortaleza, CE, which originated from an urban occupation and was characterized by low social indicators. A single case study was performed, based on the Ecological Insertion and on 10 interviews conducted with community leaders and inhabitants. The data were submitted to Content Analysis and two categories of analysis were identified: adversities experienced and factors that favor community resilience. The main adversities relate to structural difficulties, violence and stigma from violence associated with the location. CR processes are illustrated in the community struggles for basic rights and are based on the following factors: social capital, cultural ties and the infrastructure that supports the growth of the community. This demonstrates the relevance of the concept of CR in the study of adversities, such as poverty and violence, which are historically less emphasized in studies concerning $\mathrm{CR}$, even though these are the most chronic and frequent within the Brazilian context.
\end{abstract}

Keywords: Community resilience, community, social capital.

\section{Resiliência Comunitária: Um Estudo de Caso de uma Comunidade de Fortaleza, CE}

\section{Resumo}

O objetivo foi compreender processos de resiliência comunitária $(\mathrm{RC})$ e fatores a ela relacionados, através de um estudo de caso de uma comunidade de Fortaleza, CE, que teve origem em uma ocupação urbana e se caracteriza por baixos indicadores sociais e pela luta por melhorias para o lugar. Realizou-se um estudo de caso único, com base na Inserção Ecológica e em 10 entrevistas com lideranças comunitárias e moradores. Os dados foram submetidos à Análise de Conteúdo e duas categorias de análise foram

* Mailing address: Universidade de Fortaleza (UNIFOR), Avenida Washington Soares, 1321 - Edson Queiroz, Fortaleza, CE, Brazil 60811-905. Phone: (85) 3477-3219. E-mail: tercilacampos@hotmail.com and normandaaraujo@gmail.com

The authors are grateful to the Cearense Foundation for Scientific and Technological Development (FUNCAP) for the scholarship granted to the first author and to the National Council for Scientific and Technological Development (CNPq) for the Research Productivity Grant granted to the second author 
identificadas. As principais adversidades vivenciadas referem-se às dificuldades estruturais, violência e estigma de violência associado ao local. Os processos de RC são ilustrados nas lutas comunitárias em prol de direitos básicos e estão alicerçados nos seguintes fatores: capital social, laços culturais e na infraestrutura que apoia o crescimento da comunidade. Ressalta-se a relevância do conceito de RC para o estudo de adversidades, como a pobreza e a violência, as quais são historicamente menos enfatizadas nos estudos sobre RC, embora sejam as mais crônicas e frequentes no contexto brasileiro.

Palavras-chave: Resiliência comunitária, comunidade, capital social.

\section{Resiliencia Comunitaria: Un Studio de Caso de una Comunidad de Fortaleza, CE}

\section{Resumen}

El objetivo fue comprender el proceso de resiliencia comunitaria (RC) y factores a ella relacionados, a través de un estudio de casos de una comunidad de Fortaleza, CE, que tuvo origen en una ocupación urbana y se caracteriza por bajos indicadores sociales y por la lucha por mejorías en el local. Se realizó un estudio de caso único, con base en la Inserción Ecológica y en 10 entrevistas con líderes comunitarios y personas que viven en el local. Los datos se sometieron al Análisis de Contenido y se identificaron dos categorías de análisis. Las principales adversidades vivenciadas se refieren a las dificultades estructurales, la violencia y el estigma de la violencia asociada al lugar. Los procesos de RC se ilustran en las luchas comunitarias en pro de derechos básicos y se basan en los siguientes factores: capital social, lazos culturales y en la infraestructura que apoya el crecimiento de la comunidad. Se rescata la relevancia del concepto de RC para el estudio de adversidades, como la pobreza y la violencia, las cuales han sido históricamente menos consideradas en los estudios sobre $\mathrm{RC}$, aunque sean las más crónicas y frecuentes en el contexto brasileño.

Palabras clave: Resiliencia comunitaria, comunidad, capital social.

The concept of resilience gained prominence in the scientific community in the late 1970 s, and was used to describe how some individuals were able to achieve healthy development, despite high exposure to mental health risk factors (Boon, Cottrell, King, Stevenson, \& Millar, 2012; Rooke, 2015). The initial understanding of the phenomenon was that certain personal attributes made these people invulnerable. More recent research, however, understands resilience as a dynamic process in which individual characteristics relate to environmental aspects and are thus able to overcome adversities as well as enabling a strengthening and transformation (e.g., Juliano \& Yunes, 2014; Norris, Stevens, Pfefferbaum, Wyche, \& Pfefferbaum, 2008).

With the emergence of an ecosystemic view of resilience, which perceives the individual as being embedded in a web of complex relationships, the concept could be applied not only to understand adaptive capabilities presented by individuals but also by human communities and larger societies (Norris et al., 2008). Studies on community resilience seek to understand how a community, with all its strengths and vulnerabilities, deals with the impact of a collective adverse situation, and is able to cope and transform itself from it (Oliveira \& Morais, 2018).

The literature on community resilience demonstrates the existence of two main theoretical currents, one Latin American and one American. The Latin American current was led by the Argentine researcher Néstor Suárez Ojeda and is based on social epidemiology, since the communities of the Latin American countries are distinguished by poverty and social discrimination. The North American current, in which the researcher Fran Norris is the main exponent, researches resilience according to the 
most traditional concerns of health. Although the two currents do not directly connect, it is possible to perceive similarities in their theoretical models and one can try to make an attempt to integrate them.

Ojeda (2005) acknowledges the damage suffered by a community in the face of a disaster or catastrophe, but emphasizes that this painful situation can also mean mobilizing the resources and capacities of the population to promote a transformation, both physical and social in the community. The communities that present this type of response to crisis situations have a "protective shield", which allows for the metabolization of a negative event and the ability to build from it. Observation of these communities allowed the author to define the pillars of community resilience. They are: solidarity, perceived through the adhesion to the group cause, with the purpose of overcoming adversities and gaining benefits common to all; state honesty, seen through the relationship of trust between community members and their governors; cultural identity, which gives members a sense of belonging through the recognition and appreciation of what is specific to a given culture, including traditions, values, dances, and so on; social humor, the ability of some people to find comedy in their own tragedy, which favors a distancing from the problem and enables its resolution; and collective self-esteem, an attitude and feeling of pride and love that the individual has for the place where they live, an awareness of its natural beauty and identification with its customs (Ojeda, 2005; Ojeda, La Jara, \& Márquez, 2007).

According to research by Norris et al. (2008), community resilience is the process that links a network of adaptive capabilities to a positive trajectory of adaptation experienced by the community after a major trauma. This adaptation is manifested through community well-being achieved after a period of transient dysfunction. The adaptive capabilities that allow a community to present a process of resilience are: economic development, which fosters resilience insofar as it offers capability, diversity in economic resources and equality in their distribution; social capital, relations of the individual with the social networks to which he/she is incorporated, which provide social support and connection with the community; information and communication about the risks people are facing, the directions to be taken that help to raise survival levels in an emergency; and community competence, decision-making capabilities, meaningful and intentional collective action, empowerment, ability for constructive engagement in group processes, mutual trust, and willingness to work for the common good of the community (Norris et al., 2008).

Although community resilience is not a construct from Community Psychology, it is possible to perceive similarities between its proposals and concerns. Community Psychology is interested in understanding how the senses, meanings and feelings of the residents influence the way of life of the community and how this way of life changes and is reflected in its residents. Each community has within it a 'transition potential' that can be accessed through the development of the consciousness of its residents. Such potential can also generate significant transformations in community life, including overcoming poverty, inequalities and environmental destruction (Góis, 2008). Since community resilience is the ability to cope with and adapt to collective challenges, its study has the potential to bring great contributions to Community Psychology, especially if applied to interventions in situations of chronic adversity, such as drought, social inequality, lack of basic resources for survival, urban violence, among many other situations commonly found in the Brazilian and Latin American context.

An integrative review of the literature (national and international) on community resilience, from 2009 to June 2015, was carried out to identify the state of the art on the subject, specifically in regard to the concept, main contexts of adversity and factors that favor community resilience (Oliveira \& Morais, 2018). The results of the review demonstrated the predominance of publications from the United States, written 
in the English language and based on the conceptual framework proposed by Norris et al. (2008). In addition, the concept of community resilience has been predominantly used in studies that investigate how a community can cope with a disaster (e.g., earthquake, terrorist attack and nuclear accident) and be rebuilt from such adversity. Only four articles from the Latin American continent were identified, one being from Brazil, which confirms the great need for publications of Latin American origin about this subject which have the possibility of achieving greater visibility through publication in high impact journals.

The qualitative characterization of the articles indicates that the factors favoring the manifestation of resilience in communities are: social capital (social support networks in general and trusting relations among community members, the existing organizations and their leaders); the relationship of members with their place of origin (cultural ties); and an infrastructure that supports the development of community members (health, education, security, and leisure systems; Oliveira \& Morais, 2018). Thus, it is possible to perceive similarities between the factors found in the articles and the pillars of community resilience proposed by Ojeda (2005). Social capital encompasses the pillars of solidarity and state honesty. While cultural identity, social humor and collective self-esteem are linked to the members' relationship with their place of origin, which connects with the cultural ties. The attempt to integrate the results of this review with the Latin American contribution to the concept of resilience is summarized in Figure 1.

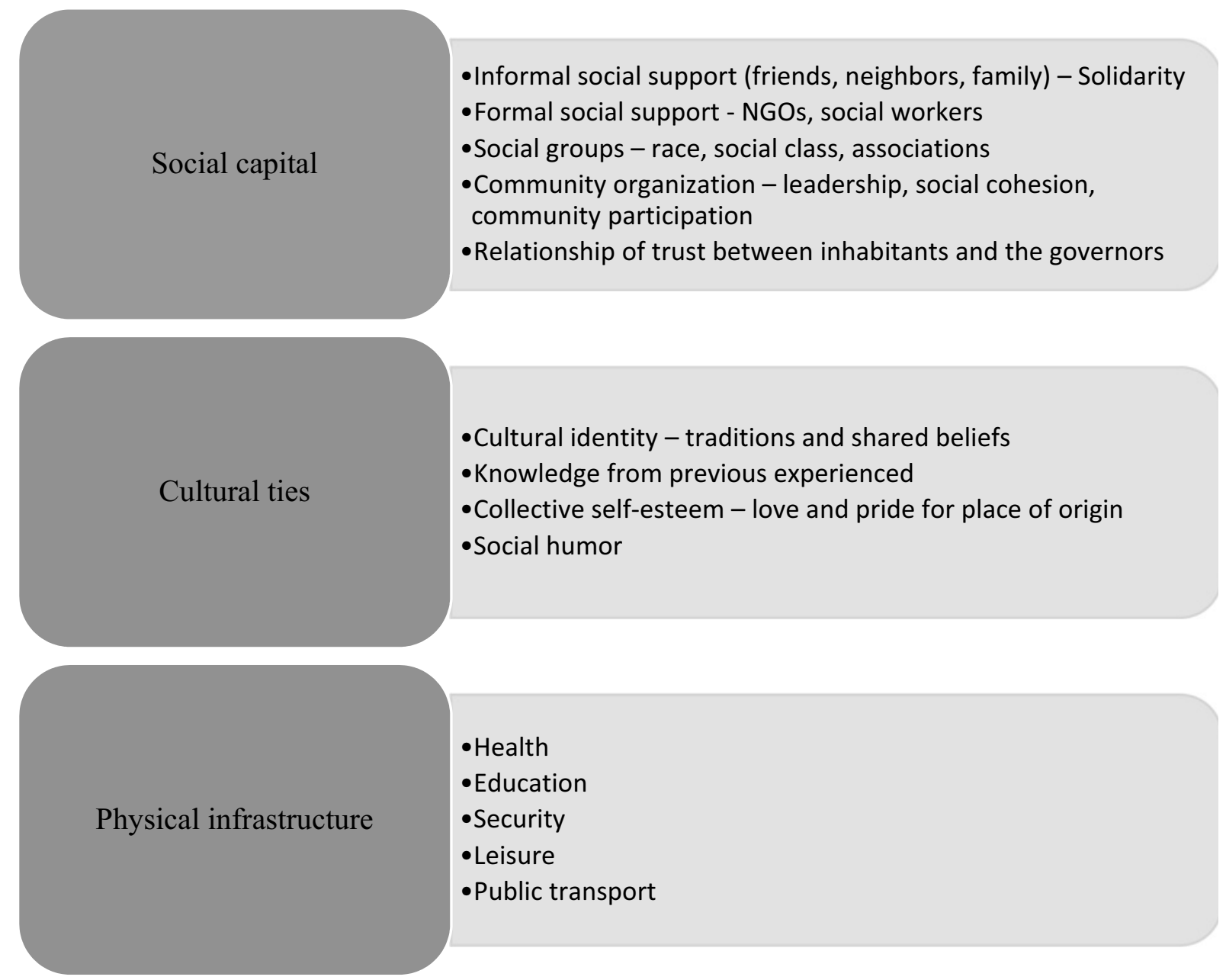

Figure 1. Factors that favor community resilience 
Despite the growing number of international studies addressing the concept of community resilience, studies published in the Portuguese language which depict the Brazilian context are still rare (e.g., Morais, Figueiredo, Rodrigues, \& Santos, 2015; Zappe, Yunes, \& Dell'Aglio, 2015), as shown in the review of Oliveira and Morais (2018). This observation highlights the need for more studies in this area and a better understanding of how resilience processes can be identified and stimulated in our communities. In this way, there is a need to validate the relevance of studies that address chronic adversities (poverty and drought, for example) experienced in Brazilian communities, as well as their forms of coping. Understanding community resilience is of great value to both the community, which can identify and strengthen its own protective factors, and to external actors who are interested in community development, for example, practitioners who operate community interventions and sources of funding that need to determine how best to invest limited resources.

The present research therefore sought to understand processes of community resilience and related factors through a case study of a community in the city of Fortaleza - Ceará, Brazil. In terms of specific objectives, our objective was to:

1. Characterize the community in relation to its location, population, history, current structure of health, education, security, leisure, social assistance teams and NGOs;

2. Describe the adversities experienced in the community context; and

3. Identify factors that favor processes of community resilience.

\section{Method}

This is a qualitative, descriptive and exploratory research, which presents a case study (Yin, 2010). The previous contact of the two authors of this article with this community was through the realization of an Extension Project, which served as the basis for choosing the same community for the case study analyzed here. The choice was therefore based on the hypothesis that this community has been experiencing throughout its history - processes of community resilience, being an emblematic case to illustrate such processes.

\section{Participants}

The participants of the research were selected from the snowball technique. Each participant indicated another one, so that it was possible to reach the number of 10 interviewees, five of whom were female and five were male, aged between 21 and 72 years $(M=40.2$ years, $S D=14.96)$. Interviews were interrupted when the saturation criterion was evaluated, that is, when the two authors evaluated that the content was repetitive (Flick, 2009). The inclusion criterion for selecting participants was to live or work in the neighborhood. The names used are fictitious for the preservation of identities.

\section{Instruments}

Semi-structured interviews. The script, written especially by the authors of this article, was composed of nine questions, the first being: "If you were to introduce your community to someone who does not know it, what would you say?" The other questions deal with the history of the place, the main adversities experienced, and the institutions and people who support the community. A field diary was used as an auxiliary tool, allowing for a detailed description of the people, places, situations and reflections experienced during the data collection.

\section{Data Collection Procedures}

This study used the Ecological Engagement as a strategy for data collection, a methodological proposal that Cecconello and Koller (2003) developed based on the Bioecological Approach to Human Development by Urie Bronfenbrenner. In the case of this research, the Ecological Engagement began in August 2014, when the first contact with a community NGO took place to carry out an extension project of the university to which the authors are linked. After the project finished, community visits continued throughout the years 2015 and 2016, intermittently. During 
this period, there were community walks, visits to the school, day care, health center and places of greater social vulnerability, in order to know the current situation of the community. The visits intensified in July and August 2016, happening at least once a week and at most three, lasting from 2 to 4 hours each. During these visits, the interviews took place, these were individual, audiotaped with an average duration of 35 minutes for each participant. Interviews were conducted at the participants' homes, in NGOs or workplaces, depending on their preference and availability. The Ecological Engagement was present in all phases of the data collection, which made it possible for the researcher to approach the researched reality and gain a broader understanding of the participants' answers. All the visits were registered by the researcher in the field diary.

\section{Data Analysis Procedures}

Data recorded in field diaries and found in documents and sites (demographic data) were systematized and described in order to reach the objective of the community description in respect to their current situation (Objective 1). The interviews were analyzed through Content Analysis (Bardin, 1995) and generated two categories of analysis, which were defined a priori, based on the objectives of the study: the adversities found in the Ayrton Senna Planalto (ASP) at community level (Objective 2); and factors that favor community resilience processes (Objective 3). The information collected in interviews, documents and field journals was integrated through the triangulation of the data. Finally, the contents of the interviews were discussed in light of the literature in regard to the area.

\section{Ethical Procedures}

The research was approved by the Ethics Committee of the author's institution of origin (Decision no. 1,444,545) and followed all the guidelines put forth in Resolutions 466/2012 and $510 / 2016$ of the National Health Council (CNS). All participants signed the Terms of Free and Informed Consent (TFIC).

\section{Results and Discussion}

Initially, the results of the study will be presented in relation to the characterization of the neighborhood, its current situation and its history. Subsequently, the two categories of analysis will be addressed: adversities experienced and factors that favor community resilience.

\section{About Ayrton Senna Planalto}

The Ayrton Senna Planalto (plateau; ASP) is a district of Fortaleza, CE, with a population of 39,446 inhabitants and one of the lowest Human Development Indexes in the city, 0.168 (City Hall of Fortaleza, 2014). The neighborhood is composed of five communities (Pantanal, Ipaumirim, Arvoredo, Cidade Nova and Renascer) and results from the occupation of a large area of land which occurred in 1990.

When asked to present the place where they live, the participants affirmed that the ASP is a neighborhood like any other, that goes through the same difficulties as the other neighborhoods in the outskirts of Fortaleza, especially in regard to structural issues. In addition, they describe ASP as a neighborhood full of potential with people seeking to improve to place. "A neighborhood of families, of citizens and civilians, of young people who also seek to fulfill their dreams. It's the corner where I was born and live and I am in no rush to leave it" (Ruan, 35 years). Among the positive characteristics of the neighborhood, they report that the people are strong, that they fight, believe in the positive change of the place and strive for this to happen.

Another aspect that characterizes ASP and generates pride for its residents is commercial development. There is a street in the neighborhood that is only for trade, where you can buy everything that the locals need. The strong point of the commerce is a large open-air market that operates daily, but it becomes busy on weekends when people from other neighborhoods go there to shop. This area of the neighborhood is quite hectic and offers all kinds of products and services, such as various types of shops, markets, bakeries, electrical goods, cafeterias, 
bicycle shops and beauty salons. However, the streets away from the center are more empty. You can find unpaved streets or streets without tarmac, vacant lots, trees and scattered garbage. There are also smaller communities within the neighborhood, with narrow streets, smaller houses and poor physical structure. There are no spaces dedicated to leisure in ASP. Although, and perhaps because of this, it is possible to observe many people in the streets, talking on the sidewalks, riding bicycles, children playing, running and flying kites.

\section{History}

ASP came about after the occupation of a large portion of unused land by a group of families who had nowhere to live. The land was divided up by the leader of the group, and each family received a piece of land the same size, they set up their huts and, some time later, built their houses, giving rise to the community called Pantanal.

And I came in here on July 27 at 10.15 p.m. with 2,100 families. What was it I said I was carrying? I was carrying a pot, I was carrying a stick to be able to... I was carrying all these things. Then I went in and cut down the bushes. Here, it was the size of nine soccer fields, cutting down things and there were a lot of plants, it was a place to dump bodies. (Celia, 72 years)

In 2003, the Town Hall of Fortaleza collected four other communities that were around the Pantanal and formed the greater neighborhood of ASP. Thus, when asked to tell the story of their neighborhood, it is the story of Pantanal that the interviewees report.

Initially, Pantanal did not have any structure for housing, there was no electric power, water, public transportation that accessed the place, schools or health clinics. In addition, there was a major conflict with the alleged landowner who attempted to have the families evicted, through threats, destroying the shanty huts and making illegitimate allegations against the leader of the movement, which resulted in his arrest more than once. The families resisted all these aggressions and, since the so-called landowner did not have all the documents legalizing the land, they were able to stay. The streets were named after historical events that marked the community, such as the date of occupation (July 27) and the date of the first major arrest of the occupation leader (January 31 ). The community gathered in formal associations and began to demand that the Town Hall provide the basic conditions for them to live there. They fought and managed to get a health clinic, several schools, the financial investment of an international NGO which worked with children, water, public transport, paving and electric power.

The struggle for energy was particularly interesting and the residents are very proud of this event. As the power company took too long to install a system, residents began making clandestine connections to the power system and set up a big screen every night in a strategic location to watch television. From time to time, this practice was denounced, but they always discovered when the officials were coming and they were able to collect up the power cables before they arrived. Tired of this situation, the residents gathered in 1991, in a large demonstration, known as the "Passeata da Lamparina" (the lamp march), demanding that electricity be installed. The movement caught the attention of the authorities, who finally met the request. During the installation of energy, the public power realized there was a need to pave the streets of the community, which generated one more conquest.

Another struggle that the residents of ASP have been fighting since the emergence of the Pantanal community is to deconstruct the negative image that people from other places have of the neighborhood. "Dangerous, violent, place of thieves and a favela" are some expressions commonly used by those who do not know the area to describe ASP, this could be identified in the interviewees' speech. This situation has encouraged some residents to strive to show the other side of ASP, its potential and all the good that the neighborhood has to offer: "So this question that was created from the 
stigma of the community, it also emerged as a factor for the community to create strategies to fight against it" (Joaquim, 48 years).

From this perspective, a neighborhood NGO developed the project TV Janela, a community TV that ran from 2003 to 2014, with the aim of changing the image of the neighborhood. The project enabled young people to produce photos and videos that would reclaim the community's history, showcase their talents and spread good news:

In other words, this transformation that was happening was also the result of the struggle of these residents... To continue living there, to say: 'This is my neighborhood, even with all the difficulties, I identify with it, I created this neighborhood. (Joaquim, 48 years)

Participants report that the struggle for community improvement occurs less intensively these days. They attribute this factor to comfort on the part of the residents, since the needs of the neighborhood are not as urgent as they were at the beginning of the occupation. The main struggles that ASP currently embrace are the need for a basic sanitation system and the promotion of youth initiatives, the latter being more urgent. An active movement for the youth in the neighborhood can be observed, through the joining of religious groups, organization of events to publicize the talents of the community and professional courses offered in the neighborhood.

\section{Category of Analysis 1 - Adversities Experienced}

The adversities that the participants reported to face at ASP can be easily related to the historical processes of urbanization in the metropolises around the world. Social inequality is reflected in the cities through socio-spatial segregation, this means that the wealthy sector is where the best opportunities for employment, education, public transportation and leisure spaces are concentrated, while the periphery has a concentration of a large population living densely in precarious housing conditions. The peripheries receive a different treatment from what is given to the "formalized" city, they are held accountable for urban violence, and excluded and marginalized. The "formalized" city takes a position of defense and protection in respect to the periphery. Thus, the path of sociospatial segregation contributes to the deepening of social differences on the urban land, making it difficult for the conviviality, mobility and integration of the popular classes in large cities (Hughes, 2004).

In the case of ASP, the consequences of the disorderly urbanization process, in which public policies did not follow the rapid population growth, can be observed in their structural deficiencies. Access to health services is restricted by the lack of medicines in the basic health clinic and by the delay in getting consultations and examinations. The neighborhood still does not have a basic sanitation system, there are no kindergartens that meet the demand of the population and public transportation is also insufficient.

Another adversity reported by the participants is urban violence. They associate this phenomenon in part with the very constitution of the community, since people and families from different places came to live together and needed to organize themselves in some way. Thus, robberies, conflicts between families and deaths in the region were common. One of the events that negatively marked the history of the community was the murder of three young people, which occurred in 1993 and became popularly known as the "Slaughter of the Pantanal". The event was widely publicized in the media as well as other situations of violence that have occurred since then, which contributes to the stigma of ASP being a dangerous and violent place. According to the participants, violence in the neighborhood has diminished over the years, but it is still present, especially in cases of youth deaths involving drug use and trafficking.

Violence is a complex and multifaceted phenomenon, expressed through intentional actions by individuals and groups directed at the other which results in physical (including death), 
psychological or social damages (Macedo, Paim, Vieira-da-Silva, \& Costa, 2001). This phenomenon, which is not restricted to criminality, is divided into three types: structural - it applies to family, economic, cultural and political systems originating from an unequal and unjust social structure that denies certain groups access to the labor market and the consumption of goods essential to life; resistance - violence produced in response to structural violence and; delinquency - assaults and crimes against the person and property. In this way, delinquency should be analyzed as a structural violence, of which everyone is an author and victim at the same time.

The interviewees share the view that the situations of violence found in ASP are very similar to those of other neighborhoods in Fortaleza, and there is no justification for the stigma of violence that the neighborhood carries. It is interesting to note that, when questioned about the adversities experienced in ASP, the participants showed much greater discomfort discussing the stigma of violence and, consequently, the prejudice and discrimination, than with the actual violence itself.

Prejudice is characterized by hostile feeling and attitude directed at an individual because they belong to a socially devalued group and suffer as a consequence behavioral discrimination, actions that value one group over another which is considered inferior, always in order to exclude, marginalize and disqualify the individuals who are discriminated against. Stigma is the labeling of these people or groups. Prejudice, discrimination and stigma are interconnected processes that feed one another (Melo, 2000) and, as we can see, are possible to be identified in ASP.

The villagers blame the media for this negative image that was created. It is interesting to note that all respondents commented on the difference between what the media shows and what actually happens in ASP. The media have wide reach in the population and have the potential to influence ideas and behaviors in relation to certain "dangerous places" with a high level of crime, generally located in the peripheries of the urban centers. The media's contribution to the formation of territorial stigmas can result in a number of negative consequences, among them the feeling of personal indignity of the residents and the symbolic degradation of the neighborhoods perceived as violent. At the same time that it spreads news about urban violence, the media strongly appeals to modern mass consumption, deepening urban rupture (Ivo, 2010; Melo, 2000).

You have this vision that's created, right? Because the people who live here, we don't commit this violence that is shown, nor are we afraid. ... the good thing here is that life is vibrant. What I like about here is that you can go out at 10, 11, 9 at night, everywhere there are people on the street. If you're from here, it's even better because they are people you know, right? Unlike other places where from morning to... midnight it's deserted, not even the neighbors themselves see or speak to each other. Not here, here there are children in the middle of the street, women, people on the sidewalk. There's still a lot of it that's good, right? (Jorge, 35 years old)

So people who have never come here have a misconception. Because it was in the newspaper, so-and-so killed so-and-so, this and that happened. But for the short time that I'm here, I don't know if it is because I keep myself to myself, I find it is normal, calm even. (Joana, 28 years old)

The association between poverty and violence permeates the imagination of society and this does not happen by chance. It is common for a study to point to a relationship between lower development rates and higher crime rates in neighborhoods, which strengthens the idea that low-income neighborhoods are also the most violent. However, it is of fundamental importance to point out that these data do not reveal a predisposition or tendency of the poor towards violence, which would correspond to a double punishability for the periphery populations (Hughes, 2004). The high crime 
rates involving young people from the periphery are the result of the complex process of violence, which is influenced by several factors, such as socioeconomic inequalities, absence of public policies that meet the basic needs of the population, intense appeal of consumerism and lack of investment in social development (Minayo, 1994).

Another difficulty related to safety in ASP is that the police are not considered protective by residents. They report cases of maltreatment of innocent people, partnerships with traffickers, and seizure of drugs for sale for their own benefit: When the police find out, they come, they take 4,000, 8,000, right? They don't arrest, sometimes they arrest, but then on the way back they release, right? They never arrive at the police station. ... They stop, and then what happens, they sell the drugs... (Ana, 56 years old)

As with society in general, the police have also historically given exclusionary and repressive treatment to the periphery, contributing to the criminalization of poverty. Poor families are exposed to various constraints in the social reality that disqualifies work as a means of obtaining resources and attributes prestige to the manifestations of force through firearms and to the possession of goods considered to be only available to the rich (Hughes, 2004).

Lastly, the lack of spaces for leisure in the neighborhood (e.g., squares and games courts) was discussed by the interviewees, a reality that has been seen as a potential risk factor for the involvement of young people with drugs and crime. Although there have been soccer fields in the neighborhood, the participants report that they became dangerous and people stopped going there. Jorge, for example, comments on the case of a young man who managed to escape from crime, tried to help a friend who was still involved and ended up getting shot and was left paraplegic, a situation that relates, among other things, to the lack of opportunities and leisure spaces for the young.

And that is what always happens to the young, this damage, this side effect, right?
When it's not one way, it's another, and there's no way out, there's no space, and no alternative, without a good education inside the home, without a good education at school, and ends up being seduced by the world of crime. (Jorge, 35 years)

Although the neighborhood has developed a lot in the course of its history and reached several achievements, the residents feel abandoned by the public power, a reality shared by other communities in the country. It is therefore perceived that the adversities faced by ASP are typical of Brazilian, Northeastern and Ceará social injustice, resulting in a lack of physical structure that accompanies population growth and a culture that condemns poverty and defends meritocracy. Therefore, the adversities are not occasional or catastrophic (earthquakes, floods, tsunamis, etc.), such as those dealt with in the literature on community resilience for the most part. On the contrary, they are continuous and chronic adversities, experienced daily by an excluded and abandoned population.

\section{Category of Analysis 2 - Factors that Favor Community Resilience}

Social capital. Social capital refers to the relationships of the individual with the social networks in which they are inserted, when there is a cohesion within the group that contributes to the improvement of citizenship and democracy. The concept has been widely discussed in the literature, and is sometimes misunderstood. One of the myths surrounding the phenomenon is that it would be the solution for all poor communities and that, once there is social capital, the community would automatically progress out of poverty (Prates, 2009). Another misconception is to imagine that associations assembled to commit crimes (gangs, organizations) constitute a type of social capital. Social capital is necessarily linked to civic participation that seeks collective benefits (Zaluar \& Ribeiro, 2009). This article considers social capital to be the relationship that has a high level of affective connection between friends, family and neighbors (bonding), more loosely connected social ties that involve 
social groups and associations (bridging) and the relationship of trust between residents and governers (linking; Aldrich \& Meyer, 2015; Poortinga, 2012).

The social capital available in the ASP community could be perceived from the beginning of the occupation to the present day. The very constitution of the neighborhood shows great community organization as families experiencing similar difficulties would meet and find the solution to the situation originating from the occupation of the land. The relationship between these families corresponds to the type of social capital known as bridging, since they are people who belong to the same social class and share a reality of deprivation of living conditions. Such a connection has the potential to contribute to the advancement of a particular group in society as long as there is solidarity and respect among members. Although the relationship between families has been permeated by conflicts, especially at the beginning of the occupation, this group managed to achieve the collective goal of finding a place to live.

In addition, the importance of the role of community leadership and solidarity is illustrated through the courage of the occupation leader, who, in search of a collective conquest, faced a major personal conflict with the possible owners of the occupied land. Soon after the occupation, the residents began to organize themselves into associations that would demand a more dignified infrastructure for the community. The various demonstrations, marches, clandestine actions that allowed access to resources such as electric power and public transportation, as well as the reports of TV Janela express social cohesion and community participation, corresponding to the social capital of bridging; and also show the relationship between residents and governors, corresponding to the social capital of linking. This enables the mobilization of political resources and is expressed by the community's ability to fight for their rights.

Currently, the formal social support network of ASP is composed of a CRAS (Social assistance Reference center) and two NGOs.
The CRAS is not located in ASP, which makes it difficult for residents to access the facilities. This situation can be attributed both to the distance and to a possible failure to promote the CRAS services. However, socially vulnerable families in the neighborhood who seek the institution are monitored and can attend the CRAS family workshop in a neighborhood church. One of the NGOs has been developing activities (play, pedagogical and social inclusion) aimed at children for more than 20 years and promotes the insertion of young people into the labor market. The other NGO in the ASP has contributed greatly to the development of the youth in the neighborhood by empowering them with audiovisual activities that help in possible future employment opportunities.

The engagement of the youth in monitoring public policies, in religious groups, and in groups that aim to show the community their qualities and their talents demonstrate the current community participation. This participation is strengthened by community leaders who are concerned about the development of these young people and the community:

If we don't have help from people, we do it ourselves, we come out asking people for help... Each one gives us ten, twenty bucks to get the ball rolling. Exactly the opposite of public policies, right? We really make it happen and that's it. (Alberto, 26 years).

Cultural ties. Cultural ties are connected to the relation of a particular group to the place where they live, and are pointed out in the literature as an important factor favoring community resilience (Nuwayhid, Zurayk, Yamout, \& Cortas, 2011; Nystad, Spein, \& Ingstad, 2014). ASP has a strong artistic and cultural expression that certainly works as a protection factor for the youth of the community who engage in the groups that encourage and promote this expression. The informal groups "Fala Favela" and "É nois Pantanal" play an important role in promoting culture, as they provide young people with new opportunities for contact with cultural expression and with critical thinking. 
We have a very strong cultural scene. We have hip hop, funk, rap, reggae, rock. We have several visual artists, painters, sculptors and graffiti artists. Dancers, we have one of the greatest dancers, two of Ceará's best break-dancers live here. (Jorge, 35 years)

The strengthening of cultural ties in a community is expressed mainly by collective self-esteem, pride and love for the place where they live (Ojeda et al., 2007). The ASP residents demonstrated a high level of collective selfesteem through the affectionate and proud way they speak of ASP. As discussed in the neighborhood presentation, they are proud of the history of struggles, economic growth and the way of life of the place. "I live here in the community and, if I had to be born again, I would want to be born in the same community" (Ruan, 35 years).

Infrastructure. The infrastructure of a community or neighborhood and its built environment form what is called the physical capital. An infrastructure that contributes to the resilience processes offers residents of a community access to health, education, social amenities, leisure, security and quality public transportation. On the other hand, a community that does not have these resources tends to present greater vulnerability and more limited possibilities of development (Ungar, 2011). The interviewees considered the physical structure of ASP to be precarious and insufficient to accommodate the growing number of residents. However, when considering the evolution of the neighborhood in this aspect, it is possible to perceive substantial growth in a short time. Ten years after occupying the land without any structure for urban coexistence, residents have already achieved the implementation of schools, health care, NGOs, associations, electric power, piped water, paving of some streets, an official public transport line and streets devoted exclusively to commerce. Undoubtedly, the neighborhood can still improve greatly in terms of infrastructure, especially in regard to the creation of leisure spaces and the implementation of a basic sanitation system. However, it is clear that the struggle for an infrastructure that allows for a better quality of life in ASP has resulted in great achievements that have contributed and continue to contribute to processes of community resilience.

Economic development is one of the adaptive capabilities described by Norris et al. (2008) and a factor clearly present in the process of community resilience experienced by ASP. In the early years of occupation, many residents were able to support their families by working in the Horticultural Products Supply Center of Ceará - Ceasa. Subsequently, the market of the neighborhood and the growth in the number of traders provided other opportunities for work in the neighborhood. Some traders reported that the national economic crisis affected sales in the ASP, however, neighborhood trade is still quite busy. Successful merchants financially help youth-oriented projects such as "É nois, Pantanal'.

\section{Final Considerations}

The article sought to understand processes of community resilience and their associated factors, through a case study of a community in the city of Fortaleza - Ceará. The ASP neighborhood, despite experiencing typical difficulties of socially excluded communities, presents a history of struggle for structural improvements and a fight against the stigma of violence that the neighborhood holds. It is possible to identify in the neighborhood the three main factors that favor community resilience described in the literature: social capital (community organization, community participation, social cohesion, leadership), cultural ties (collective identity, collective selfesteem) and infrastructure (schools, health clinic, social workers and commerce).

This research is an addition to the limited studies that investigate community resilience in contexts of chronic adversities related to poverty and social inequality. In addition, it portrays a national context, focusing on adversities that 
are common in other Brazilian communities. Regarding the literature on the subject, we sought to integrate Latin American and American community resilience models, since they both provide important contributions to the study of this phenomenon, although they deal predominantly with occasional and catastrophic adversities.

The concept of community resilience has great potential to contribute to community studies as well as Community Psychology. It is a new way of looking at communities, which must be viewed not only from their difficulties, limitations and needs, but also from their potentialities, their capability to mobilize themselves and to experience processes of community resilience. Although ASP is a neighborhood with one of the lowest HDI in the city of Fortaleza, the place is filled with pulsating, happy and creative life. This demonstrates how limited a view that is based only on official data and media-reported news can be. It is not a matter of neglecting the situations of vulnerability to which the residents are exposed, but of recognizing that the reality is extremely more complex.

Emphasis on factors that promote community resilience, as well as looking at the history of the ASP community, allows for a reading of community resilience as a "process", not simply as an outcome. Norris et al. (2008) suggest that the outcome in community resilience processes is a well-being expressed by satisfaction with life, which was repeatedly perceived in the conducted interviews. The procedural vision leads us to understand that specific processes that come together in that community constitute such achievements and there are internal and external factors that enable these achievements and are intrinsically related. The feeling of belonging to the community, the collective self-esteem, the social mobilizations that allowed the conquest of certain social rights, which in turn, fueled new struggles, and fed the self-esteem and sense of belonging. In short, a system that feedbacks on itself.

The limitation of this study refers to the profile of the participants interviewed. Although living or working in ASP were the only inclusion criteria for their selection, most of those selected had some type of leadership role in the neighborhood. The results may have been influenced by this factor, since they are people with a strong affective relationship with the place and developed critical / political thinking. The research, therefore, did not reach out widely enough to the most common residents, those without involvement in the search for improvements to ASP.

The great importance of the social achievements of the ASP throughout its history is perceived. Today we do not see the same mobilization that occurred in the first years of occupation, but we can see the prominence of the (collective) groups of young people. Future studies could lead to a greater insertion in social facilities into the community, for a longer time, especially in those groups of young people who have been shown today as having a major role in the social struggles. Finally, we emphasize the great contribution that studies accompanying interventions to promote community resilience in the Brazilian context would bring to this area of study and to social and community development.

\section{References}

Aldrich, D., \& Meyer, M. (2015). Social capital and community resilience. American Behavioral Scientist, 59(2), 254-269. http://doi. org/10.1177/0002764214550299

Bardin, L. (1995). Análise de conteúdo. Lisboa: Edições 70.

Boon, H. J., Cottrell, A., King, D., Stevenson, R. B., \& Millar, J. (2012). Bronfenbrenner's bioecological theory for modelling community resilience to natural disasters. Natural Hazards, 60(2), 381-408. http://doi.org/10.1007/s11069011-0021-4

Cecconello, A. M., \& Koller, S. H. (2003). Inserção ecológica na comunidade: Uma proposta metodológica para o estudo de famílias em situação de risco. Psicologia: Reflexão e Critica, 16(3), 515-524. http://doi.org/10.1590/S010279722003000300010 
City Hall of Fortaleza. (2014). Desenvolvimento Humano, por bairro, em Fortaleza. Retrieved from https://www.fortaleza.ce.gov.br/ noticias/prefeitura-apresenta-estudo-sobredesenvolvimento-humano-por-bairro

Flick, U. (2009). Desenho da pesquisa qualitativa. Porto Alegre, RS: Artmed.

Góis, C. W. de L. (2008). Saúde comunitária: Pensar e fazer. São Paulo, SP: Aderaldo \& Rothschild.

Hughes, P. J. A. (2004). Segregação socioespacial e violência na cidade de São Paulo: Referências para a formulação de políticas públicas. São Paulo Em Perspectiva, 18(4), 93-102.

Ivo, A. B. L. (2010). Questão social e questão urbana: Laços imperfeitos. Caderno CRH, 23(58), 17 33.

Juliano, M. C., \& Yunes, M. A. (2014). Reflexões sobre rede de apoio social como mecanismo de proteção e promoção de resiliência. Ambiente \& Sociedade, 17(3), 135-154. http://dx.doi. org/10.1590/S1414-753X2014000300009

Macedo, A. C., Paim, J. S., Vieira-da-Silva, L. M. V., \& Costa, M. D. C. N. (2001). Violência e desigualdade social: Mortalidade por homicídios e condições de vida em Salvador, Brasil. Revista de Saúde Pública, 35(6), 515-522. http://doi. org/10.1590/S0034-89102001000600004

Melo, Z. M. (2000) Estigmas: Espaço para a exclusão social [Special issue]. Revista Symposium $U C P E, 4$. Retrieved from http://www.maxwell. lambda.ele.puc-rio.br/2457/2457.PDF

Minayo, M. C. (1994). A violência social sob a perspectiva da saúde pública social. Article, 10, 07-18. http://doi.org/10.1590/S0102311X1994000500002

Morais, N., Figueiredo, D., Rodrigues, T., \& Santos, R. (2015). "Mandacaru quando fulora na seca": Um estudo sobre processos de resiliência vividos por moradores do sertão cearense. In R. Coimbra \& N. Morais (Eds.), A resiliência em questão. Perspectivas teóricas, pesquisa e intervenção. Porto Alegre, RS: Artmed.

Norris, F. H., Stevens, S. P., Pfefferbaum, B., Wyche, K. F., \& Pfefferbaum, R. L. (2008). Community resilience as a metaphor, theory, set of capacities, and strategy for disaster readiness. American Journal of Community Psychology, 41(1-2), 127-150. http://doi.org/10.1007/s10464-0079156-6
Nuwayhid, I., Zurayk, H., Yamout, R., \& Cortas, C. S. (2011, March). Summer 2006 war on Lebanon: A lesson in community resilience. Global Public Health, 6, 505-519. http://doi.org/10.1080/1744 1692.2011 .557666

Nystad, K., Spein, A. R., \& Ingstad, B. (2014). Community resilience factors among indigenous Sámi adolescents: A qualitative study in Northern Norway. Transcultural Psychiatry, 51(5), 651-672. http://doi. org/10.1177/1363461514532511

Ojeda, E. (2005). Uma concepção latino-americana: a resiliência comunitária. In A. Melillo \& E. Ojeda (Eds.), Resiliência: Descobrindo as próprias fortalezas (pp. 47-57). Porto Alegre, RS: Artmed.

Ojeda, E., La Jara, A., \& Márquez, C. (2007). Resiliência comunitária. In L. Hoch \& S. Rocca (Eds.), Sofrimento, resiliência e fé: Implicações para as relações de cuidado (pp. 33-56). São Leopoldo, RS: Sinodal.

Oliveira, A. T. C., \& Morais, N. A. (2018). Resiliência comunitária: Um estudo de revisão integrativa da literatura. Temas em Psicologia, 26(4), 17311745. http://dx.doi.org/10.9788/tp2018.4-02pt

Poortinga, W. (2012). Community resilience and health: The role of bonding, bridging, and linking aspects of social capital. Health and Place, 18(2), 286-295. http://doi.org/10.1016/j. healthplace.2011.09.017

Prates, A. A. P. (2009). Redes sociais em comunidades de baixa renda: Os efeitos diferenciais dos laços fracos e dos laços fortes. Revista de Administração Pública, 43(5), 1117-1146. $\quad$ http://doi.org/10.1590/S003476122009000500007

Rooke, M. I. (2015). Aspectos conceituais e metodológicos da resiliência psicológica: Uma análise da produção científica brasileira. Estudos e Pesquisas em Psicologia, 15(2), 671-687.

Ungar, M. (2011). Community resilience for youth and families: Facilitative physical and social capital in contexts of adversity. Children and Youth Services Review, 33(9), 1742-1748. http:// doi.org/10.1016/i.childyouth.2011.04.027

Yin, R. K. (2010). Estudo de caso: Planejamento e métodos. Porto Alegre, RS: Bookman.

Zaluar, A., \& Ribeiro, A. P. A. (2009). Teoria da eficácia coletiva e violência: $\mathrm{O}$ paradoxo do 
subúrbio carioca. Novos Estudos - CEBRAP, 84, 174-197. http://doi.org/10.1590/S010133002009000200010

Zappe, J., Yunes, M. A., \& Dell'aglio, D. (2015). Psicologia dos desastres e resiliência comunitária: Reflexões sobre o incêndio da boate Kiss em Santa Maria/RS. In R. M. Coimbra \& N. A. Morais (Eds.), A resiliência em questão:
Perspectivas teóricas, pesquisa e intervenção. Porto Alegre, RS: Artmed.

Received: 03/05/2018

$1^{\text {st }}$ revision: $30 / 09 / 2018$

$2^{\text {nd }}$ revision: $05 / 11 / 2018$

Accepted: 28/11/2018 distribution, and reproduction in any medium, provided you give appropriate credit to the original author(s) and the source, provide a link to the Creative Commons license, and indicate if changes were made. 